\title{
Die toerustingstaak van die Gereformeerde predikant: 'n praktiese bedieningsmodel
}

\author{
J.M. Vorster \\ Dept. Dogmatologie \& Ekklesiologie \\ Potchefstroomse Universiteit vir $\mathrm{CHO}$ \\ POTCHEFSTROOM \\ E-pos: dekjmv@puknet.puk.ac.za
}

\begin{abstract}
The equipping task of the Reformed minister: A practical model for ministry

The mininstry of the minister in the Reformed ( hurches in South Africa is strongly influenced by the institutional model of the ('hurch The result of this pattern of ministry is that ministry in general is solely dependent on the work of the particular offices of minister. elder and deacon. The community of the saints and the general priesthood of the believers are thus neglected. This article explores nays in which the equipping task of the minister can be effectively rearanged in order to enhance the uphuilding of the church In conclusion, it is stated that the Reformed minister can equip the believers by simultaneously using two patterns of ministry. On the one hand. the believers can be equipped by way of the ministry of the Word and Sacraments in the worship service and by the ministry of the Word in catechetical instruction and parish visiting. On the other hand, the Reformed minister can equip believers by enabling people with the gift of leadership to lead small groups in the congregation, with the altimate aim of building up the community of the saints and the general priesthood of the believers
\end{abstract}

\section{Inleiding}

Die kerklike lewe in die gereformeerde tradisie word oor die afgelope dekades grootliks gekenmerk deur die instituutmodel met sy klerikalistiese uitgangspunt. Op grond van die kerkhistoriese ontwikkeling daarvan noem Mead (1993:32) die agtergrond van hierdie model die Christendom-paradigma en bedoel daarmee die volgende: "In the Christendom Paradigm, the role of clergy was clear. It was strong, central, and unquestioned. It was a high-status role. carrying authority. Clergy were the ministry".

Hierdie model as 'n effektiewe bedieningsmodel het misluk, omdat dit te ver gevoer is en uiteindelik skeefgetrek is. Die mislukking kom na vore in die onvermoë van die instituutmodel om die belangrike leerstuk van die gemeenskap van die heiliges en die gedagte van die amp van die gelowige tot hulle reg te laat kom, asook in die verskraling van kerk-wees tot die werk van 
die besondere dienste en kerklike vergaderinge. Hierdie vereensydiging van die roeping van die kerk het gelei tot 'n funksieverlies van die kerk in die samelewing en 'n identiteitsverlies van gelowiges in die moderne lewe (Vorster, 1996:2).

Die irrelevansie en die funksieverlies van die kerk soos in bogenoemde werk uiteengesit, het egter daartoe gelei dat opnuut gekyk is na die ontwikkeling van die gemeenskap van die heiliges en die diens wat die gelowiges in die amp van die gelowige kan speel. Mead (1993:49) sê om hierdie rede dat die toerusting en gebruik van die gelowiges 'n saak van prioriteit in die kerklike lewe vandag en in die nabye toekoms behoort te wees.

Wat hy vir die hede en in die toekoms bepleit, is egter reeds vir 'n geruime tyd in baie kerklike tradisies aan die orde. Woods (1996:108) wys daarop dat die belangstelling in die ontwikkeling van die diens van die gelowige sedert 1950 toegeneem het. Hierby kan gewys word op die feit dat die bekende missioloog Kraemer (1958:167) in 1958 reeds gepleit het vir 'n "theology of the laity" waarin die gelowiges se dienswerk beskou word as 'n onvervreembare taak wat die Here aan hulle opgedra het. Kraemer het reeds in 1958 gewys op die toerustingsrol van die besondere dienste in die kerk waardeur die gelowiges, veral vir die vervulling van 'n sendingroeping opgelei kan word. Die beklemtoning van die diens van die gelowiges is ook 'n geruime tyd al 'n toenemende verskynsel in die Ekumeniese Beweging (Weber, 1963:377).

Tans is navorsing oor die wyses waarop gelowiges toegerus moet word en gebruik moet word in die kerklike diens in verskeie tradisies aan die orde van die dag. In hierdie verband kan gewys word op die werke van Arnold (1986); Stevens (1987); Bryan (1987); Pennel (1987); Fryar (1988); Stuckey (1988); Hall (1989) en Easterwood (1990). Hierdie navorsingsprojekte stel verskeie maniere voor waarop die gelowiges vanuit verskillende kerklike tradisies vir verskillende take toegerus kan word. Dit is opmerklik dat weinig nog hieroor gedoen is in die kringe van die Gereformeerde Kerke in Suid-Afrika. Wat wel gedoen is, sal deur die loop van hierdie navorsingsartikel behandel word.

Die toenemende beklemtoning van die gemeenskap van die heiliges en die amp van die gelowige moet beskou word as 'n reformatoriese verskynsel. Die beginsel dat die kerk as liggaam van Christus moet groei in geestelike volwassenheid en getalle is 'n Bybelse opdrag. Richards en Hoeldtke (1980:46) toon die feit aan in hulle behandeling van die Bybelse begrippe vir groei, opbou en volwasse word in die geloof. Hulle konkludeer;

It is clear from an examination of these terms and their use in relation to the body of Christ that the church is an organism. I.ike any organism, it is designed for growth. And, while God is the source of all increase, the 
process of growth in the body involves the mutual contribution of every member so that the whole might be built up and achieve maturity.

In die gereformeerde tradisie is reeds oortuigend aangedui dat die diens van die gelowige ontwikkel moet word deur middel van die besondere dienste van die kerk en die gemeente wat homself opbou (Ridderbos, 1971:483; Ritter, 1976:44; Schippers, 1977:13; Versteeg, 1985:26; Venter, 1988:10). In die lig van hierdie wêreldwye reformatoriese ontwikkeling word die volgende vraag ten opsigte van die Gereformeerde Kerke in Suid-Afrika in hierdie artikel aan die orde gestel: Hoe kan die bediening ingerig word sodat die tocrustingstaak van spesifiek die predikant tot sy reg kom, om sodoende die gelowiges vir hulle diens toe te rus? Hierdie vraag is tans kardinaal in die Gereformeerde bediening.

In die uitwerk van so 'n moontlike bedieningsmodel vir die effektiewe toepassing van die toerustingstaak van die predikant word Beckham (1995:25) se beeld van die kerk in aangepaste vorm gebruik. Hy vergelyk die kerk met " $n$ voël met sy twee vlerke. Albei vlerke is nodig om te vlieg. Die twee vlerke van die lewende gemeente is, volgens hom, die werk van die besondere dienste as die eerste vlerk, dit wil sê die amptelike bediening en die funksionering van die gemeente as geheel. Die tweede vlerk is die funksionering van die gemeenskap van die heiliges, dit wil sê die funksionering van die gelowiges in kleiner groepe. Albei beklemtoninge is belangrik. Die beklemtoning van die amptelike bediening lei tot eensydigheid - soos binne die instituutmodel (Dulles, 1987:34). Die beklemtoning van slégs die funksionering van die gelowiges in selgemeentes of ander wyses lei tot 'n ander eensydigheid - soos in die sogenaamde liggaamsmodel (Janse van Rensburg, 1995:625). Hierdie eensydighede moet vermy word. Binne die raamwerk van die beeld met sy balans tussen die twee "vlerke" word nou gepoog om 'n moontlike model vir die toerustingstaak van die Gereformeerde predikant uit te werk. Aandag word daarom gegee aan die toerusting deur gemeentelike bediening en die toerusting deur bediening in kleingroepe.

\section{Toerusting deur gemeentelike bediening}

In die gereformeerde tradisie word die amptelike bediening van die gemeente as ' $n$ baie belangrike beginsel beskou (Vorster, 1996:14). Hierdie beginsel word in artikel 30 van die Nederlandse geloofsbelydenis soos volg saamgevat:

... die ware kerk moet ooreenkomstig die geestelike bestuurswyse wat ons llere ons in sy Woord geleer het. regeer word. Daar moet naamlik dienaars of herders wees om die Woord van God te verkondig en die sakramente te bedien, ook ouderlinge en diakens on saam met die herder die kerkraad te vorm. 
Teen die agtergrond van hierdie beginsel word die taak van die predikant in artikel 16 van die Kerkorde van die Gereformeerde Kerke in Suid-Afrika beskryf. Die taak behels die diens van Woord er sakramente, die gebede en die toesig en tug in die gemeente saam met die ouderlinge (GKSA, 1979:17). Hierdie wyse van bediening staan prinsipieel vas en die toerustingstaak van die predikant moet enersyds binne hierdie raamwerk beredeneer word. In hierdie verband kan drie sake uitgesonder word, naamlik die Woordbediening in die erediens, die Woordbediening in kategese en die Woordbediening in herderlike sorg en toesig.

\subsection{Woordbediening in die erediens}

In die gemeentelike bediening moet die predikant se Woordbediening beskou word as die belangrikste wyse van toerusting (Leith, 1990:206). Hierdie Woordbediening sluit die amptelike Woordverkondiging in die erediens, sowel as die Woordbediening tydens herderlike sorg en kategese in. Woordbediening is immers die primêre roeping van die predikant. Prediking is “... die krag van God tot redding ..." (1 Kor. 1:18-2:5). Daarom sê Combrink (1987:111) dat die amptelike prediking die krag van die Woord van God, die kruis van Christus en die Heilige Gees konkreet aan die hoorders moet betuig.

Oor die plek en betekenis van die prediking in die opbou van die gemeente het Labuscagne (1988) besondere navorsing gedoen. Hy toon aan dat Jesus deur sy prediking die dissipels toegerus het vir die opbou van die gemeentes. Ook die prediking van die apostels het hierdie doel voor oë gehad. In die vroeë kerke het prediking 'n sentrale plek gehad. Sy finale konklusie lui soos volg:

Dit is die wil en bedoeling van die drie-enige God deur Christus dat die prediking ' $n$ sentrale en primêre plek inneem in die toerusting van die gemeente en daarom het dit ' $n$ wesentlike betekenis vir die opbou van die gemeente (Labuscagne, 1988:228).

Die amptelike prediking is dus sonder enige twyfel 'n prinsipiële gegewe waarsonder die kerk nie kan bestaan nie (Jonker, 1976:380; Pieterse, 1981:6; Vorster, 1996:72). Bright (1977:164) het in sy uiteensetting van die Bybelse betekenis van die koninkryk van God daarom ook gesê dat die kerk in die verlede, hede en toekoms altyd sal lewe in haar prediking.

Dwarsdeur die geskiedenis van die kerk was die prediking om hierdie rede hoog aangeslaan. Die omvangryke werke van Dargan (1974) en die bondige uiteensetting van Stott (1982:15) oor die geskiedenis van die prediking getuig daarvan. Deur die prediking is die kerke opgebou en het hulle, ten spyte van gebreke, gegroei en die geloof in Christus versprei. Die krag van die prediking het weerstand gebied teen heidense godsdienste en filosofiese rigtings, het kulture gekersten en 'n Christelike beskawing ontwikkel. Hoe baie ook al gesê 
kan word oor die historiese gebreke van die kerke, kan die dinamiese en ingrypende karakter van die prediking nooit ontken word nie.

Die kort prinsipiële en historiese oorsig is nodig omdat die belangrikheid en noodsaak van die prediking tans oor die afgelope dekades in baie kringe bevraagteken word (Runia, 1981:6). Die kritiek kom hoofsaaklik na vore in twee bronne. Kellerman (1988:272) sê tereg dat die kritiese vrae oor die gesag van die prediking saamgaan met die bevraagtekening van die gesag van die Skrif. Hierby kan ook gevoeg word die bevraagtekening van die noodsaak van prediking wat voortvloei uit die milieu van die moderne mens (Vos, 1995:4). Vanuit die milieu van demokratisering op baie gebiede word kritiek uitgespreek teen die teenswoordige instituutmodel van die kerk. Voorts word gevra na 'n kerk wat minder leerstellig is en meer opgaan in maatskaplike en sosiale programme. Klaas (1996:16) gee 'n treffende beskrywing van hierdie tendens in sommige kerke in die VSA. Op grond van die behoeftes van die mens word gepleit vir minder monologiese prediking en meer ervaring en deelname. Kritiek teen die instituutmodel moet egter nie die prinsipiële gegewenhede van die roeping van die kerk - soos die prediking - tersyde stel nie. Schwarz en Schwarz (1985:78) is korrek wanneer hulle sê dat daar sonder evangelisering geen kerk is nie en sonder kerk geen evangelisering is nie. Klaas (1996:16) is ook oortuig dat die kerke met hierdie neiging hulle ware missie prysgegee het.

Amptelike Woordbediening moet egter toerustend van aard wees. Hiervoor is daar drie belangrike voorwaardes. Eerstens moet weereens gestel word dat die prediking waarlik Skrifprediking moet wees. In die kerk kan immers niks anders as die Skrif verkondig word nie. Die begrippe wat die Nuwe Testament vir prediking gebruik, gee hiervan duidelik blyke (Pieterse, 1981:8; Vorster, 1996: 73). Tweedens moet die prediking 'n sterk onderrigtende inslag hê wat wyer strek as slegs die sogenaamde leerstellige prediking. Williamson en Allen (1991: 84) wys daarop dat onderrig nie net 'n element van prediking is nie, maar dat die prediking onderrig moet wees in alle opsigte. Deur die prediking moet die gelowige leer wat die Christelike leer van genade en die daaruit voortvloeiende lewe van dankbaarheid behels en watter implikasies dit het vir sy bestaan. Die gelowige moet op Sondag leer wat hy op Maandag moet doen. Daarom moet die prediking nie eensydig opgaan in wettisisme, moralisme, emosionele opwekking of geestelike belewing soos wat vandag op 'n wye vlak voorkom nie (Cilliers, 1996:3, 73). Bevindelike prediking is belangrik, maar kan nie losgemaak word van sy leerstellige onderbou of op 'n dualistiese wyse skeiding maak tussen geloofservaring en Christelike lewe nie.

Derdens moet die prediking die individu op aktuele wyse betrek. Die moderne kultuur waarin die gelowige leef, word beskryf as 'n tyd van "godsverduistering" (Verbnom, 1991:115). Daarmee word bedoel dat die gelowige op die wye lewensvlak gekonfronteer word met ingrypende 
sekularisasie. Deur die prediking, wat die evangelie konkreet vertolk binne hierdie lewensmilieu, moet die gelowige toegerus word om te lewe uit die geloof. Toerustende prediking is vertroostend en bemoedigend, maar ook appelerend, rigtinggewend en vermanend van aard.

Die plek van prediking in die toerusting van die gelowige kan nie vervang word met ander wyses van opbou en onderrig nie. Daarvoor is die Bybels-prinsipiële en histories-bewese belangrikheid van prediking te belangrik. Dat daar vandag baie gebreke in die prediking in Suid-Afrika is, word op duidelike wyse deur Cilliers (1996:21) aangetoon. Hy wys daarop dat die prediking mense veelal koud en verward laat. Op dié wyse kan prediking gelowiges nie toerus nie. Die antwoord lê nie in die devaluering van prediking ten gunste van onderlinge dialoog en ervaring nie, maar in reformasie van die prediking tot dit wat dit volgens die Bybel moet wees.

In hierdie verband kan gewys word op wat Paulus skrywe in 1 Korintiërs 2:1: "Wat my betref, broers, toe ek na julle toe gekom het om die geheimenisvolle waarheid van God aan julle te verkondig, het ek nie met hoë woorde of groot geleerdheid gekom nie." In I Korintiërs 14:6b skryf hy verder: “... Ek sal vir julle net van nut wees as ek 'n openbaring of kennis of profesie of lering aan julle meedeel". Die belangrikheid van toerustende prediking kom ook na vore in 1 Korintiërs 14:3 wat lui: "Iemand wat profeteer, rig hom tot mense en praat woorde wat geestelik opbou en bemoedig en vertroos". Prediking as toerustende onderrig uit die Woord kan nie vervang word met eensydige moralisme of die opwekking van emosie sonder die fondament van "kennis" en "lering" nie.

\subsection{Woordbediening in die kategese}

Die toerusting in die Woordbediening moet voortgesit word in die kategese. In die Gereformeerde bediening is tradisioneel aanvaar dat die predikant die eintlike kategeet is, dit wil sê, dat hy die katkisasieklasse van die verbondsjeug self waarneem. In die praktyk word egter in die meeste gevalle gebruik gemaak van hulpkragte omdat die grootte van gemeentes en gebrek aan tyd dit vir predikante moeilik maak om die taak alleen te verrig. Wanneer die praktyk benader word vanuit die leer oor die gawes van die Gees aan mense soos uitgedruk in 1 Korintiërs 12 kan daar egter tog in die kategetiese onderrig 'n prinsipiële saak uitgemaak word vir die gebruik van gelowiges wat die gawes daarvoor het. Die predikant moet hom dan nie hieraan onttrek nie, maar kan in hierdie opsig saam met ander kundiges optree as toeruster - veral waar dit gaan om die Bybels-prinsipiële aspekte van die onderrig. Hy hoef nie die enigste kategeet te wees nie, maar moet vanweë sy roeping as Woordbedienaar hierin die leiding neem. 
Die beginsel wat Richards (1970:128) ten opsigte van motiverende onderrig stel, is in hierdie opsig ook van besondere belang. Die predikant moet die kategete en die hulpkragte wat hy oplei, motiveer. En dit geskied, volgens hom, wanneer dit wat hulle leer volgens 'n vaste patroon geskied, hulle die relevansie daarvan sien, hulle kan deelneem aan die onderrigproses en hulle die vrugte van hulle opleiding in hulle lewe sien. Die kategetiese onderrig en die opleiding van hulpkragte moet dus, anders as die Woordbediening in die erediens, nie 'n monologiese eenrigtingverkeer wees nie, maar moet deur middel van kreatiewe deelname die een wat opgelei word, motiveer. Hierdie aspek van die toerusting deur die prediking is van onskatbare waarde as onderdeel in die omvattende proses van die opbou van die gemeente.

\subsection{Die Woordbediening in herderlike sorg en toesig}

Die Woord moet deur die predikant nie net in die erediens nie, maar ook aan die gelowige op persoonlike vlak na die eis van elkeen se omstandigheid verkondig word (GKSA, 1992:621). Tradisioneel is hierdie taak uitgevoer deur die praktyk van huisbesoek in die geografiese wykstelsel en siekebesoek in hospitale en aan huise van siekes. Hierdie praktyk het egter algaande in onbruik geraak omdat die belangrikheid van huisbesoek in twyfel getrek word (Louw, 1980:1). Die beperkte nuwere literatuur oor die saak kan gesien word as 'n bewys van dié stelling. In bepaalde kringe is die huisbesoek van die predikant ook vervang met spreekkamers. Hierdie praktyk druis egter in teen die praktyk wat in die bevestigingsformulier vir bedienaars van die Woord gestel word. Spreekkamerbediening bereik wel mense met bepaalde pastorale probleme, maar is nie geskik vir die toerustingsroeping wat die predikant in hierdie verband moet vervul nie omdat hy op hierdie wyse nie alle lidmate bereik nie. Vir die persoonlike toerusting bly die huisbesoek van die predikant steeds die geskikste middel (Kaptein, 1975:13).

Pieterse (1981:27) het in 1981 belangrike vrae gevra oor die geskiktheid van die geografiese wykstelsel. Hoewel hy aantoon dat moderne sosiologiese invloede die wykstelsel benadeel, benadruk hy tog die positiewe aspek dat dit in die wykstelsel gaan om gesinne en hierdie stelsel is in ooreenstemming met die verbondsgedagte. In dié stelsel word, volgens Pieterse, ook die eenheid van die geloof bo sosiale verskille gehanteer. Om hierdie rede is daar nog plek vir die wykstelsel en kan die stelsel met groot vrug in die herderlike sorg van die predikant aangewend word.

Die predikant kan sy toerustingstaak dus steeds effektief vervul deur stelselmatige en georganiseerde huisbesoek en siekepastoraat. Op hierdie wyse word die verbondsgesin betrek. Hierdie werk is een van die belangrikste take van die predikant en effektiewe huisbesoek toon definitiewe positiewe vrugte in die bediening. Die predikant en die gemeente moet albei die saak as van 
besondere belang beskou sodat die huisbesoekpatroon as een van die basiese pilare van Gereformeerde bediening behoue kan bly.

Die predikant het ook die roeping om toe te sien dat die kerkraad toegerus word en hulleself verder toerus vir die uitoefening van toesig en tug. Die bevestigingsformulier vir ouderlinge stel immers duidelik dat die ouderlinge die Woord van God deeglik moet ondersoek en hulle oefen in die rykdom van die evangelie om sodoende hulle taak te kan uitvoer (GKSA, 1992:637). Hierin moet die predikant hulle as amptelike Woordbedienaar bystaan. Gemeentes moet mekaar ook in hierdie opsig ondersteun soos in vele gevalle reeds met vrug plaasvind. Means (1993:100) stel tereg dat die ordelike beplanning van hierdie soort van toerusting van die uiterste belang is en dat dit nie lukraak na gelang van die voorkoms van probleme moet plaasvind nie.

Bogenoemde wyse van toerusting wat rus op die tradisionele Gereformeerde bedieningspraktyk is 'n prinsipiële gegewe en kan nie uit die Gereformeerde bediening weggeneem word nie. Hierdie wyse kan nie vervang word met 'n liggaamsmodel waarin die besondere dienste afgeskaal word en staatgemaak word op die onderlinge bediening van die gelowiges nie. Hierop wys Erasmus en Kellerman (1995:604) vanuit gereformeerde ekklesiologiese hoek. Aan die ander kant moet die wyse van bediening nie gesien word as die enigste wyse waarop die predikant sy toerustingstaak kan vervul nie. Die lewende gemeente het ook 'n tweede "vlerk" en dit is die funksionering van die gemeenskap van die heiliges wat deur die bediening in kleingroepe uitgebou kan word. Die moontlike waarde hiervan vir die toerustingstaak van die Gereformeerde predikant word vervolgens ondersoek.

\section{Toerusting deur bediening in kleingroepe}

Die toerusting van die gelowiges met die oog op die beoefening van die gemeenskap van die heiliges is vir die kerk van wesentlike belang. Stevens en Collins (1993:126) sê met goeie redes dat die kerk sonder hierdie aksent nie waarlik kerk is nie. Eastwood (1960:238) wys met goeie motivering daarop dat al die Protestantse tradisies die saak sedert die Reformasie beklemtoon het, maar dat nie een werklik daarin geslaag het om die volle rykdom van die leerstuk uit te werk nie. Om die gelowiges toe te rus alleen deur die gemeentelike bediening, soos hierbo beskryf is, is nie genoeg nie - soos blyk uit die gegewens van die onlangse kerkgeskiedenis. Die kleingroep as bedieningswyse is ook nodig soos Neighbour (1990:24) aantoon in sy uiteensetting, en waar die model van bediening met groot sukses toegepas is. 


\subsection{Kleingroep en nie selgemeente nie}

Die gebruik van die benaming kleingroep in hierdie artikel impliseer nie die gedagte van 'n selgemeente nie. Onder selgemeente word gewoonlik verstaan 'n klein sel van gelowiges wat buite of langs die geïnstitueerde kerk bestaan. Die sogenaamde selgemeente is die vrug van 'n kerkbeskouing waarin die belangrikheid van die besondere dienste vervaag (vgl. Woods, 1996:101; Wuthnow, 1993: 30). Hierdie neiging is latent teenwoordig by Potgieter (1995:112). Hoewel hy nie wegdoen met die besondere dienste nie, skaal hy die dienste tog af tot blote besturende dienste. Hierdie beskouing kan genoem word laitisme, teenoor die klerikalisme van die instituutmodel. Britz (1997:8) waarsku vanuit gereformeerde ekklesiologiese hoek teen hierdie eensydigheid.

Verskeie ander navorsers in die ekklesiologie het dieselfde bedenkinge soos blyk uit die volgende stellings: Wanneer kleingroep en gemeente teenoor mekaar gestel word, dra dit die kiem van gemeenteontbinding (Strauss, 1997:2). Die gevaar is dan dat die belangrike saak van Woordverkondiging sy plek verloor (Kellerman, 1997:6). Die beoefening van die gemeenskap van die heiliges en die opbou van die amp van die gelowige kan nie by die besondere dienste soos deur God gegee, verbygaan nie (Rossouw, 1988:360; Strauss, 1997:34; Janse van Rensburg, 1995 en 1997:6). Die kleingroep kan nie die geïnstitueerde kerk met die besondere dienste afskaal of vervang nie.

Met bogenoemde gevaar van klerikalisme en laitisme in gedagte word met kleingroepe in hierdie artikel daarom die volgende bedoel: die implementering van klein groepe gelowiges rondom bepaalde belangstellings, roepingsgerigthede, belange of sosiale homogeniteite. Hierdie groepe bly volkome deel van die gemeente as ' $n$ addisionele bedieningspatroon langs die bedieningspatroon vanuit die besondere dienste in die geïnstitueerde kerk soos die saak hierbo beskrywe is. Arnold (1992:27) se beeld van die gemeente as 'n byekorf sou hier as ' $n$ beskrywing kon dien. Soos 'n byekorf ' $n$ geheel is wat heg saamgestel is uit baie aktiewe onderdele, kan die gemeente gesien word as ' $\mathrm{n}$ eenheid wat bestaan uit aktiewe kleingroepe wat binne die eenheid met 'n verskeidenheid van belange besig is.

Kleingroepe in hierdie betekenis is nie ' $n$ nuwe saak in die gereformeerde bediening nie. Britz (1997:2) en Kellerman (1997:2) wys daarop dat kleingroepe in een of ander vorm reeds lankal in die Nederduitse Gereformeerde Kerk in Suid-Afrika gefunksioneer het. Hierdie praktyk is reeds in 1979 deur Barnard (1979:125) aanbeveel vir evangelisering. Tog het daar ' $n$ neiging in die gemeentebouteologie ontstaan om die kleingroep as 'n selgemeente in 'n sin teenoor die gemeente te stel. Hieroor sê Britz (1997:8) die volgende:

Sedert ongeveer 1985 het daar in oortuiging in die Ned. Geref. Kerk posgeval dat die gemeente ' $n$ kleingroep is en dat die kleingroep die 
gemeente is. Dit is 'n alternatiewe benadering wat prinsipieel verskil van die tradisionele kleingroepbediening.

Wanneer die kleingroep op hierdie wyse losgernaak word van die gemeente, lei dit tot kerkverbrokkeling. Die kleingroep is nie 'n alternatiewe kerk of bedieningswyse nie, maar 'n addisionele bedieningspatroon waardeur die gemeente opgebou word. In hierdie lig is die kleingroep by uitnemendheid geskik om beslag te gee aan die toerustingstaak van die predikant.

\subsection{Norme vir die kleingroep}

Hoe moet die kleingroep saamgestel word? In die kringe van die Gereformeerde Kerke in Suid-Afrika word dikwels die standpunt gehuldig dat die reeds bestaande geografiese wykstelsel geskik is om te dien as kleingroep. Pieterse (1981:21-30) en Kellerman (1997:11) toon egter met goeie sosiologiese redes aan dat die wykstelsel nie hiervoor geskik is nie. Aangesien geografiese wyke nie 'n beginselsaak is in gereformeerde bediening nie, behoort hierdie sosiologiese redes in berekening gebring te word.

Van hierdie redes is die volgende: Vanweë die moderne mens se drang na die privatisering van sy lewe, vorm hy vriendskappe rondom sy belangstelling en nie noodwendig in geografiese verband nie. Die feit dat lidmate geografies saamwoon, is nie meer voldoende vir goeie groepsvorming in die gemeente nie, maar belangstelling en die eiesoortige belewing van geloof is bepalend daarvoor. Hierdie verskynsel word versterk deur die mens se mobiliteit en anonimiteit. Hy wil ook kerklik-funksionele verhoudinge hê. Wyke het ook nie altyd geskikte leiers wat in die groep die leiding kan neem nie. Die sterk gesinskarakter van die wyk bevoordeel die amptelike bediening soos hierbo verduidelik is, maar vir die kleingroep is dit 'n nadeel omdat die groepe sterk op gemeenskaplike belange afgestem is. Kinders en alleenlopendes kom nie altyd in wyke tot hulle reg nie.

Die belangrikste norm vir die samestelling van die kleingroep is gemeenskaplike belangstelling. Naas die wyke moet "interessegroepe" bestaan wat rondom belangstelling saamgetrek word. Die groepe kan ook die vorm aanneem van diensgroepe wat rondom 'n bepaalde diens groepeer. Gesamentlike belangstelling bring groepskohesie mee (Pieterse, 1981:28). Die groep moet ook so saamgestel word dat die gelowiges wat daaraan behoort, nie net dieselfde belangstelling het nie, maar ook dieselfde gawes het om hierdie gawes in diens van mekaar en die hele gemeente te stel.

'n Verdere belangrike norm word deur Neighbour (1990:194) soos volg gestel in sy leidinggewende en invloedryke werk oor die kleingroep: 
The cell is the 'Basic Christian Community'. The Church is formed from them and is the sum of them. Cells never grow larger than fifteen people and multiply as they reach this figure. There are no other activities which exist in competition with the cells. Everything in the church is an extension of them and flows from their combined strength.

By die belangrike saak wat Neighbour hier stel, is dit nodig om as voorbehoud te stel dat die diensgroep geaktiveer moet word uit die besondere dienste binne die raamwerk van die gemeente as geheel. Voorts is dit belangrik om daarop te let dat die lede van die kleingroep binne die raamwerk van die reeds genoemde vereistes vir die kleingroep van tyd tot tyd gewissel moet word sodat die groepe nie "kerkies binne 'n kerk" word en sodoende die eenheid van die gemeente versteur nie.

'n Baie belangrike norm vir die kleingroep is dat die groep gereeld moet byeenkom. Die groep moet nie net in naam bestaan of byeenkom wanneer daar ' $n$ bepaalde noodsaak is nie. Hierdie sporadiese samekomste is dikwels die geval waar gemeentes reeds van diensgroep- of kieingroepbediening gebruik makk. Hierdie groepe moet verkieslik weekliks byeenkom vir Bybelstudie en gebed met die oog op die saak waarmee hulle besig is. So word groepskohesie gevorm en die noodsaaklike groepsdinamika ontwikkel. Die kleingroep moet aktief wees om positiewe resultate te lewer.

\subsection{Voordele van die kleingroep}

Beckham (1995:30) vat die voordele van die aktiewe kleingroep in hulle organiese verhouding met die gemeente, soos dit reeds in die praktyk waar dit toegepas is, bewys is soos volg saam:

- Die kleingroep funksioneer deur die week en brei die gemeentelike aktiwiteit uit vanaf Sondae na weeksdae.

- Die groepe vorm vir mense wat deur die verkondiging van die evangelie tot geloof kom die poort na die gemeente. Hierdie nuwe lidmate word in die kleingroep tuisgemaak en as sodanig ook in die gemeente.

- Die groepe dra in hulle byeenkomste in die week die fees van die erediens verder.

- Die lede gee as gevolg van die hegte organiese samehang van die groep aan mekaar rekenskap.

- Daar word leiers geproduseer.

- Ware geloofsgemeenskap vind plaas. 
- Die "vir mekaar"-tekste in die Bybel vind besondere uitdrukking (vgl. in hierdie verband ook Van Heyningen, 1996:29).

- Afgedwaaldes en kerkvervreemdes asook ongelowiges word makliker bereik.

- Vermeerdering van groepe vind plaas soos die gedagte deur die gemeente posvat.

- Die groepe bring groei en betrokkenheid in die gemeente.

Die belangrikste van hierdie positiewe resultate is dat die kleingroepe ruimte bied vir intense toerusting. Roscam Abbing (1978:37) het gesê dat die kleingroep nie kan funksioneer sonder toerusting nie. In hierdie opsig kom die noodsaak van toerusting en die predikant se toerustingstaak dus op organiese wyse by mekaar uit. Hoe hierdie model in die praktyk vir toerusting gebruik kan word, word ten slotte bespreek.

\subsection{Die kleingroep as toerustingsgeleentheid}

Binne die gemeente kan 'n groot hoeveelheid kleingroepe wat rondom belange, gawes, roepingsgeleenthede en sosiale heterogeniteite gevorm is, bestaan. Hierdie groepe kan onder andere wees: Bybelstudiegroepe, belydenisstudiegroepe, jeuggroepe, vrouegroepe, groepe vir jong egpare of jong ouers, evangeliseringsgroepe, gebedsgroepe, diakonale diensgroepe ensovoorts. Hierdie lys kan nog verder uitgebrei word solank die groepe met kerklike sake besig is.

Die moontlikheid van die ryke verskeidenheid van hierdie groepe in die gemeente wys dadelik uit dat die predikant onmoontlik al hierdie groepe self kan toerus. Dit is egter, soos in die instituutmodel die praktyk is, nie nodig nie omdat daar mense in die gemeente is wat die gawe van leierskap ontvang het (1 Kor. 12; 1 Kor. 14:26). Hierdie leierskap moet ontwikkel word (Neighbour, 1994:35). Die taak van die kerkraad is om die gawes van leierskap in die gemeente te identifiseer. Kirkpatrick (1995:39) maak die volgende belangrike opmerking in hierdie verband:

If your small-group ministry is central to your congregation's life and mission, your group leaders have very important roles to play. Effective group leadership requires particular abilities and developed skills. In a word, your ministry thrives on the gift of leadership. This means you need to take much care in recruiting your potential leaders. In fact, selection of potential small-group leaders should receive the same kind of attention as does the selection of church officers. 
Die vereistes, moontlikhede en indiensstelling van die kleingroepleiers word op 'n gereformeerde beginselbasis deur Oostenbrink (1996:127) bespreek. Dit is nie nodig om sy resultate hier te herhaal nie, behalwe om te sê dat kleingroepleierskap ' $n$ besondere geleentheid is om opbou in die gemeente, korporatiewe spiritualiteit en diensgerigtheid te bevorder. Die werwing en toerusting van hierdie leiers onder mans, vroue en kinders in die gemeente is van kardinale belang vir die bevordering van die gemeenskap van die heiliges en die amp van die gelowige. Hiermee moet die kerkraad erns maak.

Wanneer die leiers in die gemeente geïdentifiseer en gewerf is, dan kan hulleself ' $n$ kleingroep of twee groepe van vyftien lede elk vorm. Hierdie groepe word dan deur die predikant self gelei. Sy taak is om hierdie leiers toe te rus sodat hulle weer die leiding kan neem in hulle eie groepe. Die predikant, as leraar en Woordbedienaar lè die beginselgrondslag waarop die leierskap in die uiteindelike kleingroepe uitgeoefen word. Richards (1975:133) gee in gefundeerde aanduiding van wat hierdie leierskap behoort te behels. Die predikant moet ook 'n koördinerende en voortgesette opleidingsrol speel. In hierdie proses kan hy ook gebruik maak van ander lidmate wat in toerustingsvaardighede geskool is. Uiteindelik bly hy egter, kragtens sy roeping as toeruster (Ef. 4:12), verantwoordelik vir die Bybelse en gereformeerd-konfessionele en prinsipiële aard van die toerusting.

As 'n voorbeeld van die wyse waarop die toerusting kan geskied, kan gewys word op 'n bepaalde geval. 'n Kleingroep wat die taak aanvaar het om siekes in hospitale te besoek se leier word byvoorbeeld soos volg toegerus: Die predikant rus hom toe om Bybelstudie te kan lei met 'n spesifieke gerigtheid op siekeversorging en om leiding te gee in hierdie verband. Hierdie leier neem uiteindelik die leiding in die groep. Hulle kom gereeld bymekaar vir gebed en om Bybelstudie te doen oor die prinsipiële vereistes van hulle taak en verrig die taak fisies in ooreenstemming met die "vir mekaar"-tekste in die Bybel. Die groep moet onder leiding van die toegeruste leier as groep funksioneer en nie slegs optree wanneer siekes onder hulle aandag kom nie.

Die groot praktiese vraag is of die predikant vanweë sy baie pligte in die bediening van die Woord, soos vroeër uiteengesit, die tyd gaan vind om ook die toerusting te doenl? Hierop kan twee antwoorde gegee word. Eerstens kan met reg gesê word dat die predikante oor die algemeen in die Gereformeerde bediening nog te veel vasgevang is in die instituutmodel wat beteken dat hy in allerlei vorme van gemeenteorganisasie, wat nie werklik sy taak is nie, vasdraai. Voorbeelde hiervan is: Hy is voorsitter van die eiendomskommissie, boukommissie, finansieskommissie en lei al die Bybelstudiegroepe self. Hierdie werk en die ander onnodige take wat aan die predikant opgedra word, kan gedoen word deur gelowiges wat die gawes daarvoor het en daarvoor geskool is. 
Tweedens moet in die Gereformeerde bediening ernstig besin word oor spesialisering in die bediening. Predikante het ook verskillende gawes en die verskeidenheid van hulle gawes moet deur die gemeente ten volle benut word. As 'n predikant die besondere gawe van toerusting het, behoort hy, waar ' $n$ gemeente meer as een predikant kan bekostig, daarvoor afgesonder te word. Wanneer predikante hulle prioriteite volgens hulle taak van Woord en sakramentsbediening, diens van gebede, toesig en toerusting reg bepaal en take wat nie hiermee verband hou nie vermy, kan die toerusting deur middel van kleingroepe saam met die amptelike bediening tot sy reg kom.

\section{Konklusie}

Die toerustingstaak van die predikant moet geskied deur middel van die twee "vlerke" van die Gereformeerde bediening. Hierdie twee vlerke is enersyds die amptelike bediening van Woord en sakramente, diens van gebede, toesig en toerusting in die erediens as gesamentlike aanbidding, die kategese en herderlike sorg en toesig by huisbesoek en siekepastoraat. Hierdie amptelike bediening betrek die gemeente as geheel en is gerig op die opbou van die geloof en daaglikse lewensheiliging. Andersyds moet die predikant hierdie roeping vervul deur leiers van 'n groot verskeidenheid kleingroepe op te lei en prinsipieel toe te rus sodat hulle die kleingroepe effektief en doelgerig kan lei. Deur die ordelike funksionering van die kleingroepe binne die gemeente word die gemeenskap van die heiliges en die amp van die gelowige versterk en die gemeente as geheel in onderlinge diens en liefde opgebou en word volledig uitdrukking gegee aan die opdrag van Efesiërs 4:12.

\section{Bibliografie}

ARNOLD, J. 1992. The big book on small groups. Downers Grove : InterVarsity Press.

ARNOLD, T.W. 1986. Equipping Christians to worship in the home. San Fransisco : Golden Gate Baptist Theological Seminary.

BARNARD, A.C. 1979. Die plek en betekenis van die kleingroep. (In De Klerk, J.J., red. Evangelistiek. Pretoria : N.G. Kerkboekhandel. p. 125-146.)

BECKHAM, W.A. 1995. The second reformation: Reshaping the church for the twenty-first century. Houston : Touch Publications.

BRIGHT, J. 1977. The authority of the Old Testament. London : SCM Press.

BRITZ, R.M. 1997. Kleingroepbediening in die Ned. Geref. Kerk. 'n Kerkhistoriese perspektief. Fakulteit Teologie OVS : Ongepubliseerde lesing by die Teologiese dag te Mooigenoeg. 11 Februarie 1997.

BRYAN, C.M. 1987. Equipping laity for a caring ministry. Atlanta : Chandler School of Theology at Emory University.

CILlIERS, J. 1996. Die uitwissing van God op die kansel. Ontstellende bevindinge oor Suid-Afrikaanse prediking. Kaapstad : Lux Verbi. 
COMBRINK, H.J.B. 1987. Die prediking van Paulus. (In Combrink. H.J.B., red Bediening en bedienaar. Kaapstad : L ux Verbi. p. 102-114.)

DARGAN, 1974. A history of preaching. Grand Rapids : Baker Book House.

DULLES, A. 1987. Models of the church. New York: Double Day.

EASTWOOD, C. 1960 . The priesthood of all believers. An examination of the doctrine from the Reformation to the present day. London: The Epworth Press.

EASTWOOD, S. 1990. Apostolate: Equipping laymen for ministry. Texas : Midwestern Theological Seminary.

ERASMUS. I.M. \& KELLERMAN, J.S. 1995. Gemeentebou se liggaamsmodel: 'n Kerkbegrip van onder. Nederduirse Gereformeerde Teologiese Tydskrif. 36(4):604-616.

FRYAR, J.D. 1988. Equipping parishioners through increased knowledge and understanding of spiritual gifts. New York : Trinity Lutheran Seminary.

GEREFORMEERDE KERKE IN SUID-AFRIKA. 1979. Kerkorde van die Gereformeerde Kerk in Suid-Afrika, soos gewysig deur verskillende sinodes. Potchefstroom : Admin. Buro van die Gereformeerde Kerk.

GEREFORMEERDE KERKE IN SUID-AFRIKA. 1992. Die berynde Psalms en Skrilberymings. Potchefstroom : Calvyn Jubileum Boekefonds.

GKSA.

$k y k$

GEREFORMEERDE KERKE IN SUID-AFRIKA

HALL, P.E. 1989. Equipping facilitators to enhance ministry through the application of small group dynamics in Bible study. San Fransisco : Golden Gate Baptist Theological Seminary.

JANSE VAN RENSBURG, J. 1995. Perspektiewe op 'n kontemporctre gereformeerde bediening. In die Skriflig. 29(4):623-644. Des.

JANSE VAN RENSBURG, J. 1997. Kleingroepe mits ...! 'n Diakoniologiese benadering. Fakulteit Teologie UOVS : Ongepubliseerde lesing by die Teologiese dag te Mooigenoeg. 11 Februarie 1997.

JONKER, W.D. 1976. Die Woord as opdrag. Gedagtes oor die prediking. Pretoria : N.G. Kerkboekhandel.

KAPTEIN, R. 1975. Het huisbezoek. Problematiek en methode in een veranderde gemeente Baarn : Ten Have.

KELLERMAN, J.S. 1988. Amp en prediking - prediker in verantwoording. (In Rossouw, P.J. Gereformeerde ampsbediening. Pretoria : N.G. Kerkbockhandel. p. 272-285.)

KELLERMAN, J.S. 1997. Kleingroepbediening in die kerk: Die praktyk. Fakulteit Teologie UOVS : Ongepubliseerde lesing by dic Teologiese dag te Mooigenoeg. 11 Februarie 1997.

KIRKPATRICK, T.G. 1995. Small groups in the church. A handbook for creating community. New York: The Alban Institute.

KLAAS, A.C. 1996. In search of the unsearched. New York: The Alban Institute.

KRI:AMER, 11. 1958. A theolngy of the laity. London : Butterworth Press. 
LABUSCAGNE, G.C.P. 1988. Die plek en betekenis van die prediking in die opbou van die gemeente. Potchefstroom : PU vir CHO. (Th.D.-proefskrif.)

LEITH, J.H. 1990. Calvin's doctrine of the proclamation of the Word and its significance for today. (In George, T. ed. John Calvin and the Church. A prism of reform. Westminister : John Knox Press. p. 206-229.)

LOUW, D.J. 1980. Op soek na die huisgenote van die geloof. Riglyne vir huisbesoek. Pretoria : N.G. Kerkboekhandel.

MEAD, L.B. 1993. The once and the future church. Reinventing the congregation for a new mission frontier. New York: The Alban Institute

MEANS, J.E. 1993. Effective pastors for a new century. Grand Rapids : Baker Books.

NEIGHBOUR, R.W. 1990. Where do we go from here. A guidebook for the cell group church. Houston : Touch Publications.

NEIGHBOUR, R.W. 1994. The shepherd's guidebook. Spiritual and practical foundations for cell group leaders. Singapore : Touch Ministries International.

OOSTENBRINK, J.W. 1996. Korporatiewe leierskap en kleingroepleierskap. Potchefstroom : PU vir CHO. (Th.D.-proefskrif.)

PENNEL, J.T. 1987. Equipping and motivating the laity for the ministry of evangelism through the local church. Atlanta : Chandler School of Theology at Emory University.

PIETERSE, H.J.C. 1981. Kan die wykstelsel nog werk? Nederduitse Gereformeerde Teologiese Tydskrif, 22(1):21-30, Maart.

POTGIETER, M. 1995. 'n Nuwe Bybelse lewenswyse. George : Lewensvreugde.

RICHARDS, L.O. 1970. Creative Bible teaching. Chicago : Moody Press.

RICHARDS, L.O. 1975. A theology of Christian education. Grand Rapids : Zondervan.

RICHARDS, L.O. \& HOELDTKE, C. 1980. A theology of church leadership. Grand Rapids : Zondervan.

RIDDERBOS, H.N. 1971. Paulus. Ontwerp van zijn theologie. Kampen : Kok.

RITTER, K. 1976. Paul's concept of charisma and the ministry of the laity. London : University Microfilms International.

ROSCAM ABBING, P.J. 1978. Komen als geroepen. Over de gemeente die haar roeping vervult, en over de kerkraad die haar daar bij helpt. s'Gravenhage : Boekencentrum.

ROSSOUW, P.J. 1988. Gereformeerde ampsbediening. Pretoria : NG Kerkboekhandel.

RUNIA, K. 1981. Heeft preken nog zin? Kampen : Kok.

SCHIPPERS, K. 1977. De gemeente als leergemeenschap. Kampen : Kok.

SCHWARZ, F. \& SCHWARZ, C.A. 1985. Theologie des Gemeinde-aufbaus. NeukirchenVluyn : Aussaat.

STEVENS, R.P. 1987. Liberating the laity: Equipping the saints for ministry. Downers Grove : InterVarsity Press.

STEVENS, R.P. \& COLLNS, P. 1993. The equipping pastor. A system approach to congregational leadership. New York : The Alban Institute.

STOTT, J.R.W. 1982. I believe in preaching. London: Hodder and Stoughton. 
STRAUSS. P. 1997. Die kerk en die kleingroep - kerkregtelike aantekeninge. Fakulteit Teologie: UOVS. Ongepubliseerde lesing by dic Teologiese dag te Mooigenoeg. 11 Februarie 1997.

STUCKEY, R.H. 1988. Equipping volunteer church workers to perform more effective ministry. San Fransisco : Golden Gate Baptist Theological Seminary.

VAN HEYNINGEN. C.J. 1996. Kleingroepe as "n ruimte vir die funksionering van die amp van die gelowige. Potchefstroom : PU vir CHO. (Th.B.-skripsie.)

VENTER, C.J.H. 1988. 'n Nuwe-Testamentiese profiel van 'n gemeente wat homself opbou. (In Venter, C.J.H., red. God bou op deur sy Woord. Potchetstroom : PU vir (HO). p. 10-27.)

VERBOOM, W. 1991. Prediking in een tijd van godsverduistering. Theologia Reformala. 34(2):115-134. Jun.

VERSTEEG, I.P. 1985. Kijk op de kerk. De structuur van de gemeente volgens het Nieuwe Testament. Kampen : Kok.

VORSTER, J.M. 1996. Is die kerk funksioneel? Gedagtes oor Gereformeerde kerkvernuwing in 'n postmoderne kontcks. Potchefstroom : Potchefstroomse Teologiess Publikasies.

VOS, C.J.A. 1995. Die blye tyding. Homiletiek uit 'n hermeneuties-kommunikatiewe perspekticf. Pretoria : Raad vir Gessteswetenskaplike Navorsing.

WEBER. H. 1963. The rediscovery of the laity in the Ecumenical Movement. (In Neill, S.C: \& Weber, H. The layman in Christian history. A project of the Department on the laity of the World Council ol Churches. London: SCM Press. p. 377-394.)

WIL LIAMSON, C.M. \& ALLEN, R.J. 1991. The teaching minister. Westminister : John Knox.

WOODS, C.J, 1996. Congregational megatrends. New York: The Alban Institute.

WUTHNOW, R. 1993. Christianity in the twenty-first century. Reflections on the challenges ahead. Oxford : Oxford University Press. 
